\title{
ANALISIS FAKTOR-FAKTOR YANG DIPERTIMBANGKAN KONSUMEN DALAM KEPUTUSAN PEMBELIAN PRODUK KEK PISANG VILLA KOTA BATAM
}

\author{
Rini Mayangsari ${ }^{1}$ ) Rusda Irawati $^{2}$ ) \\ 1) Prodi Administrasi Bisnis Terapan Politeknik Negeri Batam, email: rinimayangsari226@yahoo.com \\ 2) Prodi Administrasi Bisnis Terapan Politeknik Negeri Batam, email: ira@ polibatam.ac.id
}

\begin{abstract}
This study aims to determine what factors are taken into consideration consumers in product purchasing decisions Kek Pisang Villa Batam. Technique data collection using questionnaires and documentation. Methods of data analysis used in this research is descriptive analysis and confirmatory factor analysis (CFA). The results showed that of the 20 indicators analyzed, can form six new factors namely factor Product Quality, Brand Image, Product Pricing, Form of Packaging, Competitors and Quality Packaging. While most dominant factor consumers consider the product purchasing decisions Kek Pisang Villa is a factor Quality Products with a value of $24322 \%$ variance.
\end{abstract}

Keywords: Brand, Factor Analysis, Kek Pisang Villa, Packaging, Price, Quality.

abstrak

Penelitian ini bertujuan untuk mengetahui faktor-faktor apa saja yang dipertimbangkan konsumen dalam keputusan pembelian produk Kek Pisang Villa kota Batam. Teknik pengumpulan data menggunakan kuesioner dan dokumentasi. Metode analisis data yang digunakan dalam penelitian ini adalah analisis deskriptif dan analisis faktor konfirmatori (CFA). Hasil penelitian menunjukkan dari 20 indikator yang dianalisis, dapat terbentuk 6 faktor baru yaitu faktor Kualitas Produk, Brand Image, Harga Produk, Bentuk Kemasan, Competitor/Pesaing dan Mutu Kemasan. Sedangkan faktor yang paling dominan dipertimbangkan konsumen dalam keputusan pembelian produk Kek Pisang Villa adalah faktor Kualitas Produk dengan nilai varians sebesar 24.322\%.

Kata Kunci : Analisis Faktor Konfirmatori, Harga, Kek Pisang Villa, Kemasan, Kualitas, Merek. 


\section{PENDAHULUAN}

Perkembangan teknologi dan informasi sangat berperan penting dalam bidang pemasaran, di mana para pemasar berkompetisi untuk memperbaiki serta memperbaharui konsep pemasaran yang sudah ada. Kecanggihan informasi membuat konsumen dengan mudah memperoleh informasi tentang produk yang akan dibeli guna memenuhi kebutuhannya.

Konsumen biasanya mempertimbangkan produk yang akan mereka konsumsi atau mereka beli sebelumnya sesuai dengan selera dan kriteria produk. Apalagi jika produk yang mereka beli adalah produk makanan seperti kue atau juga kek. Banyak faktor-faktor yang harus dipertimbangkan dalam pemilihan dan pembelian kue sesuai dengan kriteria dan atribut dari produk.

Atribut melekat pada produk ataupun yang menjadi bagian dari produk tersebut yang terdiri atas harga, merek, kualitas, kemasan, kelengkapan fungsi dan layanan purna jual. Masih sedikit perusahaan yang memperhatikan faktor-faktor tersebut sebagai acuan untuk meningkatkan omset perusahaan. Faktor-faktor yang seperti itu harus diterapkan pada perusahaan-perusahaan khususnya yang memproduksi produk makanan seperti Kek Pisang Villa, Nay@dam, Kek Buah Naga, Kek Durian Felicia dan sebagainya.

PT. Indonesia Villajaya adalah perusahaan manufaktur yang memproduksi Kek Pisang Villa. Kek Pisang Villa pada mulanya merupakan sebuah industri rumahan yang sangat sederhana hingga kemudian berkembang menjadi perusahaan retail terbesar yang menggarap pasar oleh-oleh khas Batam. Produk utama yang dihasilkan adalah Kek Pisang dan Kue Bingke. Kek Pisang Villa memiliki banyak varian rasa diantaranya adalah Villa Original, Villa Blackforest, Villa Blueberry, Villa Choconut, Villa Pandan Cheese, Villa Brownies, Villa Buah Naga, Villa Bingka Original Pandan dan sebagainya. Selain produk utama, Kek Pisang Villa juga menjual produk konsinyasi seperti Bayam Edan, Kerupuk Ijo, dan sebagainya. Kek Pisang Villa juga menjual cokelat-cokelat, permen, dan bentuk cemilan lainnya untuk para wisatawan yang datang ke Batam.

Semakin berkembang pesatnya usaha tersebut, Kek Pisang Villa memiliki banyak pesaing diantaranya adalah Kek Buah Naga,
Nay@dam, Kek Durian Felicia, Kue Bingka Bakar dan lain-lain. Maka dari itu untuk mengatasi terjadinya penurunan minat beli konsumen terhadap oleh-oleh khas Batam khususnya Kek Pisang Villa, perusahaan perlu memperhatikan faktor-faktor yang menjadi pertimbangan para konsumen dalam membeli produk yaitu faktor harga, kualitas, kemasan, dan merek. Sehingga PT. Indonesia Villajaya lebih siap menghadapi persaingan di masa yang akan datang.

Berdasarkan uraian tersebut, penulis tertarik untuk mengangkat tema, dengan memilih judul "Analisis Faktor Yang Dipertimbangkan Konsumen Dalam Keputusan Pembelian Produk Kek Pisang Villa di Kota Batam”.

\section{Rumusan Masalah}

Berdasarkan latar belakang masalah yang telah dikemukakan sebelumnya, maka permasalahan pokok yang akan di bahas adalah sebagai berikut:

Faktor-faktor apa saja yang keputusan pembelian produk Kek Pisang Villa.

Dari faktor yang terbentuk, faktor manakah yang paling dominan dipertimbangkan konsumen dalam keputusan pembelian produk Kek Pisang Villa.

\section{Tujuan Penelitian}

Tujuan yang ingin dicapai dengan diadakannya penelitian ini adalah sebagai berikut:

Mengidentifikasi faktor-faktor apa saja yang dipertimbangkan konsumen dalam keputusan pembelian produk Kek Pisang Villa.

Mengidentifikasi faktor manakah yang paling dominan dipertimbangkan konsumen dalam keputusan pembelian produk Kek Pisang Villa.

\section{Manfaat Penelitian} lain:

Sedangkan manfaat penelitian ini antara

Manfaat Praktis, bagi perusahaan sebagai bahan masukan dan pertimbangan perusahaan mengenai faktor-faktor yang jadi pertimbangan konsumen dalam keputusan pembelian Kek Pisang Villa. 
Rini \& Rusda,anal isis faktor-faktor yang dipertimbangkan konsumen dalam keputusan pembelian ....

Manfaat Teoritis

Bagi pembaca, sebagai tambahan referensi bagi pembaca dan acuan dalam penelitian yang sama masa yang akan datang.

Bagi penulis, dapat meningkatkan pengetahuan dan kemampuan menulis dalam berfikir ilmiah khususnya yang berkaitan dengan faktor-faktor yang dipertimbangkan konsumen dalam keputusan pembelian Kek Pisang Villa.

\section{KAJIAN PUSTAKA}

1. Ruang Lingkup Pemasaran

Menurut Abdullah dan Tantri (2012) pemasaran adalah sebuah sistem dari kegiatan bisinis merencanakan, menentukan harga, mempromosikan dan mendistribusikan barang dan jasa yang dapat memuaskan keinginan pasar-pasar konsumen.

\section{Faktor-faktor yang Dipertimbangkan Konsumen}

Menurut Tjiptono (2008) dalam Sudrajad dan Andriani (2015) atribut produk adalah unsur-unsur produk yang dipandang penting oleh konsumen yang dapat dijadikan dasar untuk mengambil keputusan pembelian. Atribut produk adalah faktor yang dipertimbangkan oleh konsumen dalam mengambil keputusan pembelian suatu produk seperti harga, merek, kualitas, kemasan, kelengkapan fungsi dan layanan purna jual.

\section{Keputusan Pembelian}

Menurut Kotler dan Armstrong (2008) dalam Jariah (2012) proses pengambilan keputusan tersebut merupakan sebuah pendekatan penyelesaian masalah yang terdiri atas 5 tahap yaitu sebagai berikut:

1. Pengenalan Masalah

2. Pencarian Informasi (Information Search)

3. Evaluasi Alternatif (Evaluation of Alternatives)

4. Keputusan Pembelian (Purchase Decisions)

\section{Perilaku Pasca Pembelian (Post Purchase Behavior)}

\section{Penelitian Terdahulu}

1. Sudrajad ${ }^{1} \&$ Andriani $^{2}$ (2015), meneliti Pengaruh Atribut Produk Terhadap Keputusan Konsumen Dalam Pembelian Produk Abon Jamur Tiram Di Perusahaan Ailanifood Kota Malang Jawa Timur. Hasil penelitian ini menunjukkan bahwa keempat atribut produk yang dianalisis berpengaruh secara signifikan terhadap keputusan pembelian konsumen terhadap produk abon jamur ailani, kecuali atribut merek.

2. Marisca (2014), meneliti Analisis Faktor Konfirmatori Untuk Tingkat Kepuasan Pengunjung Perpustakaan Universitas Negeri Yogyakarta. Hasil penelitian ini menunjukkan bahwa indikator-indikator yang mempengaruhi tingkat kepuasan pengunjung perpustakaan Universitas Negeri Yogyakarta adalah faktor responsiveness, security, reliability, tangibles, competence, credibility, courtesy, access, understanding the customer, dan communication.

3. Jayakusumah (2011), meneliti Analisis Faktor-Faktor Yang Mempengaruhi Konsumen Dalam Keputusan Pembelian The Celup Sariwangi. Hasil penelitian ini menunjukkan bahwa faktor-faktor Yang Mempengaruhi Konsumen Dalam Keputusan Pembelian Teh Celup Sariwangi didapat 8 faktor yang terbentuk diantaranya faktor Psikologis, Produk, Sosial, Distribusi, Harga, Promosi, Individu dan Pelayanan. Sedangkan faktor yang paling dominan mempengaruhi konsumen dalam keputuan pembelian teh Sariwangi yaitu faktor psikologis dengan nilai varians $18.734 \%$.

\section{METODE PENELITIAN \\ Rancangan penelitian}

Penelitian ini meneliti mengenai "Analisis Faktor Yang Dipertimbangkan Konsumen Dalam Keputusan Pembelian Produk Kek Pisang Villa" dengan penelitian kuantitatif. Pendekatan penelitian yang dilakukan ini melalui beberapa tahapan, yakni diawali dengan 
mengumpulkan data melalui penyebaran kuesioner kepada sejumlah responden yang menjadi sampel penelitian, menentukan instrumen penelitian, metode yang digunakan, serta menganalisis data yang sudah terkumpul kemudian disajikan dalam bentuk skripsi.

\section{Populasi dan Sampel}

Populasi dalam penelitian ini adalah seluruh konsumen yang membeli produk Kek Pisang Villa pada outlet-outlet yang ada di Kota Batam. Teknik penentuan responden pada penelitian ini yaitu probability sampling, yaitu proportionale stratifiled random sampling (populasi tidak homogeny) adalah teknik penentuan sampel dilakukan secara acak dengan memperhatikan strata yang ada, artinya setiap strata terwakili sesuai proporsinya. Sampel yang diambil adalah konsumen yang membeli produk Kek Pisang Villa pada lokasi-lokasi yang telah ditentukan yaitu outlet-outlet Kek Pisang Villa di Kota Batam. Sampel tersebut ditentukan berdasarkan banyaknya transaksi penjualan setiap outlet untuk 1 bulan terakhir yaitu bulan Januari 2016. Sampel akan diambil menggunakan rumus Slovin. Rumus Slovin untuk menentukan ukuran sampel minimal (n), jika diketahui ukuran populasi $(\mathrm{N})$ pada taraf signifikansi $\alpha$. Diketahui $\mathrm{N}=336$, taraf signifikansi sebesar $(\alpha=0,05)$. Berdasarkan rumus tersebut diperoleh jumlah sampel sebesar 182.6 dan dibulatkan menjadi 183 sampel. Maka, jumlah responden dalam penelitian ini adalah sebanyak 183 responden untuk 10 outlet Kek Pisang Villa di Kota Batam.

\section{Jenis dan Sumber Data}

Adapun jenis dan sumber data yang digunakan dalam penelitian ini data primer dan sekunder.

\section{Teknik Pengumpulan Data}

Teknik pengumpulan data yang dilakukan penulis adalah:

a. Kuesioner

Merupakan teknik pengumpulan data yang dilakukan dengan memberikan daftar pernyataan untuk diisi oleh para responden dan diminta untuk memberikan pendapat atau jawaban atas pernyataan yang diajukan. Untuk mengukur jawaban responden, maka digunakan pendekatan Skala Likert dengan menggunakan 4 kategori yaitu Sangat
Setuju (4), Setuju (3), Tidak Setuju (2) dan Sangat Tidak Setuju (1).

b. Dokumentasi

Merupakan data-data yang diperoleh dari setiap bagian yang berkaitan dengan penelitian seperti profil perusahaan, sejarah berdirinya usaha, struktur organisasi, data penjualan produk, data outlet, data klasifikasi produk.

\section{Validitas dan Reliabilitas}

Uji instrumen penelitian dengan menggunakan analisis validitas dan reliabilitas.

Uji validitas yang digunakan dalam penelitian ini adalah validitas konstruk (Construct Validity). Hasil $\mathrm{r}_{\mathrm{xy}}$ dibandingkan dengan $r_{\text {tabel }}$ product moment dengan $\alpha=5 \%$, jika $r_{x y}>r_{\text {tabel }}$ maka alat ukur dinyatakan valid.

Berdasarkan hasil uji validitas menggunakan SPSS 20.0 diperoleh bahwa variabel Harga $\left(\mathrm{X}_{1}\right)$, Kualitas $\left(\mathrm{X}_{2}\right)$, Kemasan $\left(X_{3}\right)$ dan Merek $\left(X_{4}\right)$ memiliki nilai $r_{\text {hitung }} \geq r_{\text {tabel }}$ dengan nilai $r_{\text {tabel }}(0.1451)$ yang berarti bahwa setiap instrumen dari item pernyataan dinyatakan valid. Nilai $r$ tabel dicari pada signifikansi $5 \%$ dengan persamaan $\mathrm{Df}=\mathrm{n}-\mathrm{k}=$ $183-2=181$.

Setelah melakukan pengujian validitas maka dilanjutkan dengan melakukan pengujian reliabilitas. Uji reliabilitas akan dilakukan dengan menggunakan uji statistik Alpha Cronbach $(\alpha)$. Dengan ketentuan bahwa variabel yang dinyatakan reliabel (dapat dipercaya) apabila nilai Alpha Cronbach $(\alpha)$ di atas nilai kritis 0,6 $(\alpha>0,6)$. Dari hasil pengolahan data menggunakan SPSS 20.0 diperoleh bahwa variabel Harga $\left(\mathrm{X}_{1}\right)$ Cronbach's Alpha adalah $(0.751 \geq 0.6)$, Kualitas $\left(\mathrm{X}_{2}\right)$ Cronbach's Alpha adalah $(0.787 \geq 0.6)$, Kemasan $\left(\mathrm{X}_{3}\right)$ Cronbach's Alpha adalah $(0.695 \geq 0.6)$ dan Merek $\left(\mathrm{X}_{4}\right)$ Cronbach's Alpha adalah $(0.758 \geq 0.6)$. Dengan demikian dapat disimpulkan bahwa alat ukur untuk item pernyataan $\left(\mathrm{X}_{1}\right),\left(\mathrm{X}_{2}\right),\left(\mathrm{X}_{3}\right)$ dan $\left(\mathrm{X}_{4}\right)$ dapat dipercaya (reliable) dan data telah layak untuk digunakan pada analisis selanjutnya.

\section{Metode Analisis Data}

Metode analisis yang digunakan untuk menganalisis data yang diperoleh adalah analisis deskriptif dan statistik inferensial. Statistik Inferensial yang digunakan dalam penelitian ini adalah uji analisis faktor.

Analisis faktor yang digunakan pada penelitian ini adalah analisis faktor konfirmatori 
Rini \& Rusda,anal isis faktor-faktor yang dipertimbangkan konsumen dalam keputusan pembelian ....

(CFA). Analisis faktor konfirmatori yaitu suatu teknik analisis faktor yang secara apriori telah diketahui dan ditentukan terlebih dahulu variabel-variabel mana saja yang berhubungan dengan faktor-faktor mana saja (Gudono, 2011) dalam Marisca (2014). Apriori dalam pengertian ini adalah suatu anggapan sebelum peneliti mengetahui, melihat, atau meneliti keadaan yang sebenarnya. Pada penelitian ini peneliti menggunakan CFA dikarenakan peneliti telah mengambil teori yang telah ada sebelumnya yang kemudian akan diterapkan pada objek yang akan diteliti oleh peneliti.

Langkah-langkah yang dilakukan dalam pengujian analisis faktor konfirmatori yaitu:

1. Melakukan uji Kaisyer-Meisyer-Olkin (KMO) measure of sampling adequacy dan Barlett Test of spericity sebagai tindak lanjut apakah indikator tersebut layak dilakukan analisis faktor atau tidak. KMO measure of sampling adequacy adalah sebuah indeks untuk membandingkan besarnya nilai koefisien korelasi yang diamati terhadap besarnya korelasi parsial. Nilai KMO yang dikehendaki agar dapat dilakukan analisis faktor konfirmatori adalah lebih dari 0,5. Apabila KMO dan Barlett test telah memberikan kesimpulan yang tepat, barulah analisis faktor dilakukan.

2. Langkah yang harus dilakukan selanjutnya adalah menghitung anti-image matrices.

3. Communalities adalah total variance yang dijelaskan oleh faktor yang diekstrak.

4. Pada Total Variance Explained yang perlu diperhatikan adalah faktor yang nilai eigennya lebih dari 1 , hal ini dikarenakan nilai eigen yang kurang dari 1 tidak signifikan.

5. Selanjutnya untuk mendiskripsikan eigenvalue secara visual dibuat scree plot.

6. Kemudian menentukan component matrix. Component matrix disajikan dalam bentuk tabel, dalam tabel ini berisikan factor loading atau nilai korelasi antara setiap faktor dan variabel-variabel analisis. Tidak semua variabel dalam component matrix dapat ditentukan keanggotaannya, oleh karena itu diperlukan rotasi.
7. Rotasi yang dilakukan pada penelitian ini adalah rotasi ortogonal dengan menggunakan metode rotasi Varimax. Rotasi Varimax merupakan rotasi tegak lurus yang bertujuan untuk meningkatkan daya interpretasi dari faktor-faktor yang didapatkan. Apabila variabel-variabel sudah dapat ditentukan keanggotaannya, maka terbentuklah faktor-faktor pembentuk.

Pada penelitian ini peneliti menggunakan software SPSS 20.0 yang telah menyediakan fasilitas untuk membantu proses perhitungan menggunakan analisis faktor konfirmatori.

\section{HASIL DAN PEMBAHASAN \\ Karakteristik Responden}

\section{Jenis Kelamin}

Dari total jumlah responden sebanyak 183 orang, responden dengan jenis kelamin perempuan lebih dominan yaitu sebanyak 101 responden dengan persentase sebesar $55.2 \%$. Maka dapat diketahui bahwa konsumen Kek Pisang Villa rata-rata adalah perempuan. Hal ini dikarenakan lebih banyak perempuan yang berbelanja pada outlet Kek Pisang Villa dibandingkan lakilaki.

\section{Kelompok Usia}

Dari total jumlah responden sebanyak 183 orang, responden dengan usia produktif yaitu 24-30 tahun sebanyak 51 responden dengan persentase sebesar 27.9\%. Maka dapat diketahui bahwa konsumen Kek Pisang Villa merupakan konsumen dengan usia produktif. Hal ini dikarenakan konsumen Kek Pisang Villa lebih banyak yang berasal dari luar kota dengan usia 2430 tahun sehingga peminat dari Kek Pisang Villa dominan berusia produktif.

\section{Pendidikan Terakhir}

Dari total jumlah responden sebanyak 183 orang, responden dengan pendidikan terakhir yang lebih dominan yaitu SMA/sederajat sebanyak 95 responden dengan persentase sebesar 51.9\%. Maka dapat diketahui bahwa konsumen Kek Pisang Villa rata-rata memiliki pendidikan terakhir SMA/sederajat. 


\section{Pekerjaan}

Dari total jumlah responden sebanyak 183 orang, responden dengan pekerjaan sebagai karyawan dominan yaitu sebanyak 41 responden dengan persentase sebesar 22.4\%. Maka dapat diketahui bahwa konsumen Kek Pisang Villa rata-rata bekerja sebagai karyawan.

5. Pembelian yang ke-

Dari total jumlah responden sebanyak 183 orang, rata-rata responden melakukan pembelian produk Kek Pisang Villa yang ke-2 kali yaitu sebanyak 76 responden dengan persentase sebesar $41.5 \%$.

6. Produk Pilihan

Dari total jumlah responden sebanyak 183 orang, produk kek pisang villa yang menjadi pilihan responden yaitu villa original sebanyak 63 responden dengan persentase sebesar $34.4 \%$. Hal ini dikarenakan produk Kek Pisang Villa yang memiliki harga paling murah yaitu villa original, selain itu analisis faktor konfirmatori berdasarkan nilai KMO dan Barlett's Test. rasanya juga enak dan tidak banyak campuran. Sehingga bagi yang tidak suka banyak campuran pada kek, dapat memilih rasa villa original.

\section{Hasil Analisis Faktor Konfirmatori}

Selanjutnya setelah pembahasan kuesioner, maka dilakukan pembahasan untuk analisis faktor. Berikut ini adalah penjelasan dan langkah-langkah mengenai hasil pengolahan data dengan menggunakan analisis faktor.

\section{Uji Validitas}

Pengujian validitas dilakukan dengan menggunakan analisis faktor yang merujuk pada hasil perhitungan Keiser-Meyer Olkin (KMO) Measure of Sampling Adequacy. Pengujian dilakukan dalam beberapa tahap sampai ditemukan semua item pernyataan dalam kondisi valid atau memiliki nilai $K M O$ lebih dari 0.5. Berikut disajikan output dari SPSS versi 20.0 terhadap pengujian validitas dengan menggunakan

Tabel 1. KMO and Bartlett's Test

\begin{tabular}{|c|c|c|}
\hline \multicolumn{2}{|c|}{$\begin{array}{l}\text { Kaiser-Meyer-Olkin Measure of Sampling } \\
\text { Adequacy. }\end{array}$} & .736 \\
\hline & Approx. Chi- & 1291 \\
\hline $\begin{array}{l}\text { Bartlett's Test of } \\
\text { Sphericity }\end{array}$ & $\begin{array}{l}\text { Square } \\
\text { Df } \\
\text { Sig. }\end{array}$ & $\begin{array}{r}.745 \\
190 \\
.000\end{array}$ \\
\hline
\end{tabular}

Sumber : Data diolah, 2016

Berdasarkan tabel di atas, dapat dilihat bahwa angka KMO dan Bartlett Test adalah $0.736(>0.5)$ dengan tingkat signifikansi 0.000 . Artinya sampel sudah memadai untuk dilakukan analisis lebih lanjut atau $73.6 \%$ variansi dapat dijelaskan oleh faktor tersebut. Maka dari itu variabel dan sampel yang ada dapat dianalisis lebih lanjut.
Analisis selanjutnya adalah dengan memeriksa Measure of Sampling Adequacy (MSA). Hal ini bertujuan untuk mengetahui apakah proses pengambilan sampel telah memadai atau belum, yaitu dapat dilihat dari Anti-Image Correlation $\left.(\ldots)^{a}\right)$. Nilai MSA pada uji validitas tahap 1 dapat dilihat pada tabel berikut:

Tabel 2. Nilai Measure of Sampling Adequacy (MSA)

\begin{tabular}{cc}
\hline Indikator & $\begin{array}{c}\text { Measure of Sampling } \\
\text { Adequacy }(\text { MSA) }\end{array}$ \\
\hline $\mathrm{X}_{1.1}$ & 0.619 \\
$\mathrm{X}_{1.2}$ & 0.626 \\
$\mathrm{X}_{1.3}$ & 0.702 \\
$\mathrm{X}_{1.4}$ & 0.694 \\
$\mathrm{X}_{1.5}$ & 0.673 \\
$\mathrm{X}_{2.1}$ & 0.680 \\
$\mathrm{X}_{2.2}$ & 0.734 \\
$\mathrm{X}_{2.3}$ & 0.818
\end{tabular}


Rini \& Rusda,anal isis faktor-faktor yang dipertimbangkan konsumen dalam keputusan pembelian ....

\begin{tabular}{cc}
\hline Indikator & $\begin{array}{c}\text { Measure of Sampling } \\
\text { Adequacy }(\text { MSA) }\end{array}$ \\
\hline $\mathrm{X}_{2.4}$ & 0.711 \\
$\mathrm{X}_{2.5}$ & 0.810 \\
$\mathrm{X}_{3.1}$ & 0.803 \\
$\mathrm{X}_{3.2}$ & 0.780 \\
$\mathrm{X}_{3.3}$ & 0.610 \\
$\mathrm{X}_{3.4}$ & 0.692 \\
$\mathrm{X}_{3.5}$ & 0.728 \\
$\mathrm{X}_{3.6}$ & 0.763 \\
$\mathrm{X}_{4.1}$ & 0.779 \\
$\mathrm{X}_{4.2}$ & 0.799 \\
$\mathrm{X}_{4.3}$ & 0.792 \\
$\mathrm{X}_{4.4}$ & 0.802 \\
\hline
\end{tabular}

Sumber : Data diolah, 2016

Pada tabel di atas dapat dilihat bahwa nilai Measure of Sampling Adequacy (MSA) untuk semua indikator sudah berada diatas 0.5 (MSA $>0.5)$, artinya ke 20 indikator tersebut dapat dilakukan analisis lebih lanjut.

\section{Indikator-indikator yang} dipertimbangkan konsumen dalam keputusan pembelian produk Kek Pisang Villa kota Batam

Berdasarkan hasil uji instrumen, data yang diperoleh sudah valid dan reliabel, sehingga dapat dilakukan analisis lanjut yang diperlukan dalam analisis faktor konfirmatori. Berikut akan disajikan hal-hal yang perlu dijabarkan dalam analisis faktor konfirmatori.

\section{Communalities}

Communalities adalah total variance yang dijelaskan oleh faktor yang diekstrak. Pada analisis faktor konfirmatori yang diekstrak hanyalah common variance, sehingga tidak salah jika nilai common variance kurang dari satu. Berikut disajikan output SPSS versi 20.0 terhadap communalities.

Tabel 3. Communalities

\begin{tabular}{lrr}
\hline & Initial & Extraction \\
\hline $\mathrm{X}_{1.1}$ & 1.000 & .604 \\
$\mathrm{X}_{1.2}$ & 1.000 & .728 \\
$\mathrm{X}_{1.3}$ & 1.000 & .711 \\
$\mathrm{X}_{1.4}$ & 1.000 & .748 \\
$\mathrm{X}_{1.5}$ & 1.000 & .654 \\
$\mathrm{X}_{2.1}$ & 1.000 & .533 \\
$\mathrm{X}_{2.2}$ & 1.000 & .731 \\
$\mathrm{X}_{2.3}$ & 1.000 & .708 \\
$\mathrm{X}_{2.4}$ & 1.000 & .676 \\
$\mathrm{X}_{2.5}$ & 1.000 & .606 \\
$\mathrm{X}_{3.1}$ & 1.000 & .457 \\
$\mathrm{X}_{3.2}$ & 1.000 & .603 \\
$\mathrm{X}_{3.3}$ & 1.000 & .766 \\
$\mathrm{X}_{3.4}$ & 1.000 & .631 \\
$\mathrm{X}_{3.5}$ & 1.000 & .741 \\
$\mathrm{X}_{3.6}$ & 1.000 & .635 \\
$\mathrm{X}_{4.1}$ & 1.000 & .702 \\
$\mathrm{X}_{4.2}$ & 1.000 & .686 \\
$\mathrm{X}_{4.3}$ & 1.000 & .674 \\
$\mathrm{X}_{4.4}$ & 1.000 & .573 \\
\hline
\end{tabular}




\section{Extraction Method: Principal Component Analysis.}

\section{Sumber : Data diolah, 2016}

Berdasarkan tabel di atas, dapat dilihat bahwa sebagai berikut:

1. Variabel Tingkat keterjangkauan harga $\left(\mathrm{X}_{1.1}\right)$ angkanya adalah 0.604 hal ini menunjukkan bahwa sekitar $60.4 \%$ varians dari variabel Tingkat keterjangkauan harga $\left(\mathrm{X}_{1.1}\right)$ bisa dijelaskan oleh faktor yang terbentuk,

2. Variabel Tingkat kesesuaian harga dengan kualitas produk $\left(\mathrm{X}_{1.2}\right)$ angkanya adalah 0.728 hal ini menunjukkan bahwa sekitar $72.8 \%$ varians dari variabel Tingkat kesesuaian harga dengan kualitas produk $\left(X_{1.2}\right)$ bisa dijelaskan oleh faktor yang terbentuk,

3. Variabel Tingkat kesesuaian harga dengan rasa $\left(\mathrm{X}_{1.3}\right)$ angkanya adalah 0.711 hal ini menunjukkan bahwa sekitar $71.1 \%$ varians dari variabel Tingkat kesesuaian harga dengan rasa $\left(\mathrm{X}_{1.3}\right)$ bisa dijelaskan oleh faktor yang terbentuk, dan seterusnya.

\section{Total Variance Explained}

Pada Total Variance Explained yang perlu diperhatikan adalah nilai eigen yang lebih dari $1(>1)$, hal ini dikarenakan nilai eigen yang kurang dari 1 tidak signifikan. Berikut disajikan dalam bentuk tabel:

Tabel 4. Total Variance Explained

\begin{tabular}{|c|c|c|c|c|c|c|}
\hline \multirow[b]{2}{*}{ Component } & \multicolumn{3}{|c|}{ Initial Eigenvalues } & \multicolumn{3}{|c|}{ Extraction Sums of Squared Loadings } \\
\hline & Total & ariance & $\begin{array}{r}\text { Cumulative } \\
\%\end{array}$ & Total & ariance & Cumulative $\%$ \\
\hline 1 & 4.864 & 24.322 & 24.322 & 4.864 & 24.322 & 24.322 \\
\hline 2 & 2.162 & 10.812 & 35.134 & 2.162 & 10.812 & 35.134 \\
\hline 3 & 2.001 & 10.003 & 45.137 & 2.001 & 10.003 & 45.137 \\
\hline 4 & 1.655 & 8.274 & 53.411 & 1.655 & 8.274 & 53.411 \\
\hline 5 & 1.276 & 6.379 & 59.790 & 1.276 & 6.379 & 59.790 \\
\hline 6 & 1.207 & 6.033 & 65.823 & 1.207 & 6.033 & 65.823 \\
\hline 7 & .950 & 4.749 & 70.572 & & & \\
\hline 8 & .794 & 3.970 & 74.542 & & & \\
\hline 9 & .691 & 3.456 & 77.998 & & & \\
\hline 10 & 639 & 3.193 & 81.191 & & & \\
\hline 11 & .560 & 2.800 & 83.991 & & & \\
\hline 12 & .547 & 2.733 & 86.724 & & & \\
\hline 13 & .464 & 2.321 & 89.046 & & & \\
\hline 14 & .418 & 2.088 & 91.133 & & & \\
\hline 15 & .383 & 1.913 & 93.046 & & & \\
\hline 16 & .345 & 1.725 & 94.771 & & & \\
\hline 17 & .333 & 1.664 & 96.435 & & & \\
\hline 18 & .273 & 1.366 & 97.801 & & & \\
\hline 19 & .239 & 1.196 & 98.997 & & & \\
\hline 20 & .201 & 1.003 & $\begin{array}{r}100.00 \\
0\end{array}$ & & & \\
\hline
\end{tabular}

\section{Sumber : Data diolah, 2016}

Berdasarkan tabel tersebut terlihat bahwa ada 20 indikator yang dimasukkan dalam analisis faktor konfirmatori. Dilihat dari nilai eigen yang lebih dari $1(>1)$ telah diekstrak atau direduksi 4 faktor yang digunakan penulis sebelumnya menjadi 6 faktor dengan masing-masing varians sebagai berikut:

Variansi faktor $1=\frac{\text { Total Loadings }}{20} \times 100 \%$

$=\frac{4.864}{20} \times 100 \%=24.322 \%$

Variansi faktor $2=\frac{\text { Total Loadings }}{20} \times 100 \%$

$=\frac{2.162}{20} \times 100 \%=35.134 \%$ 
Rini \& Rusda,anal isis faktor-faktor yang dipertimbangkan konsumen dalam keputusan pembelian ....

........dan saterusnya sampai variansi faktor 6

\section{Scree Plot}

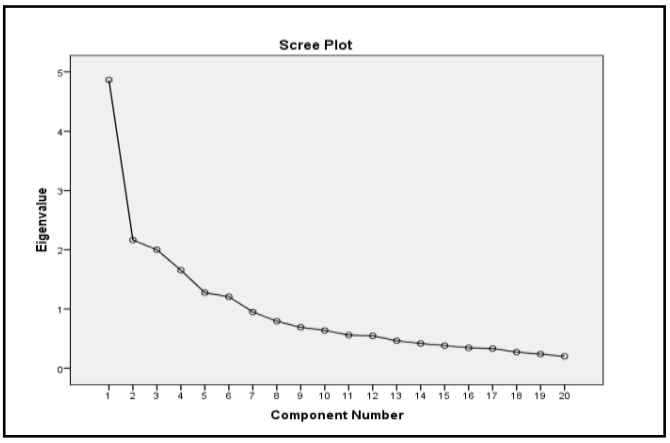

Gambar 1. Hasil Scree Plot Hubungan Eigenvalue dengan Faktor

Gambar 1 garis vertikal menunjukkan nilai eigen, sedangkan garis horisontal menunjukkan banyaknya indikator. Jika diperbesar akan terlihat lebih jelas berapa indikator yang memiliki nilai eigen lebih dari 1. Ada 6 titik yang memiliki nilai eigen di atas 1, ini berarti indikator yang akan dibentuk ada 6 indikator.

\section{Component Matrix}

Langkah berikutnya dalam analisis faktor konfirmatori adalah menjelaskan component matrix. Component matrix menjelaskan distribusi ke-20 indikator ke dalam 6 faktor yang terbentuk. Nilai component matrix mutlak karena menunjukkan korelasi, dapat dilihat pada tabel berikut:

Tabel 5. Component Matrix ${ }^{\mathrm{a}}$

\begin{tabular}{ccccccc} 
& \multicolumn{6}{c}{ Component } \\
\cline { 2 - 7 } & 1 & 2 & \multicolumn{1}{c}{3} & \multicolumn{1}{c}{4} & \multicolumn{1}{c}{5} & \multicolumn{1}{c}{.0717} \\
\hline $\mathrm{X}_{1.1}$ & .234 & .584 & .417 & .073 & .161 & -.059 \\
$\mathrm{X}_{1.2}$ & .301 & .577 & .458 & -.001 & .178 & -.250 \\
$\mathrm{X}_{1.3}$ & .444 & .633 & .260 & .209 & .019 & .048 \\
$\mathrm{X}_{1.4}$ & .565 & .511 & .045 & .171 & -.265 & .258 \\
$\mathrm{X}_{1.5}$ & .476 & .308 & -.087 & .055 & -.500 & .267 \\
$\mathrm{X}_{2.1}$ & .251 & -.242 & .577 & -.027 & .266 & -.082 \\
$\mathrm{X}_{2.2}$ & .510 & -.428 & .457 & .181 & .174 & -.126 \\
$\mathrm{X}_{2.3}$ & .599 & -.413 & .311 & .283 & .007 & -.043 \\
$\mathrm{X}_{2.4}$ & .498 & -.414 & .321 & .274 & -.247 & .131 \\
$\mathrm{X}_{2.5}$ & .591 & -.347 & .149 & .097 & -.156 & .285 \\
$\mathrm{X}_{3.1}$ & .369 & .004 & -.022 & -.357 & .308 & .312 \\
$\mathrm{X}_{3.2}$ & .475 & .013 & -.303 & .029 & .491 & .210 \\
$\mathrm{X}_{3.3}$ & .319 & .082 & -.415 & .313 & .585 & .211 \\
$\mathrm{X}_{3.4}$ & .435 & .004 & -.462 & .406 & -.007 & -.252 \\
$\mathrm{X}_{3.5}$ & .597 & .008 & -.375 & .275 & -.068 & -.404 \\
$\mathrm{X}_{3.6}$ & .611 & .028 & -.306 & .096 & -.078 & -.389 \\
$\mathrm{X}_{4.1}$ & .505 & -.025 & -.065 & -.574 & -.091 & -.324 \\
$\mathrm{X}_{4.2}$ & .578 & -.050 & -.022 & -.540 & .054 & -.235 \\
$\mathrm{X}_{4.3}$ & .620 & -.121 & -.162 & -.481 & -.097 & .088 \\
$\mathrm{X}_{4.4}$ & .584 & -.051 & -.180 & -.220 & -.041 & .383 \\
\hline Extraction Method: Principal Component Analysis. & \multicolumn{5}{c}{} \\
\hline a. 6 components extracted.
\end{tabular}

Sumber : Data diolah, 2016 
Pada tabel di atas disajikan angkaangka yang merupakan faktor loading atau besar korelasi antara suatu indikator dengan variabel $1,2,3,4,5$ dan 6 . Karena masih ada indikator yang tidak memiliki perbedaan yang nyata dengan beberapa indikator lainnya, yaitu masih terdapat nilai loading atau korelasi yang kurang dari 0.5. Maka indikator tersebut tidak dapat dimasukkan ke salah satu faktor atau variabel dengan melihat besar korelasinya. Karena itu perlu dilakukan rotasi faktor untuk memperjelas kedudukan indikator tersebut.

\section{Rotated Component Matrix}

Rotated Component Matrix merupakan hasil rotasi dari componentr matrix. Hal ini bertujuan untuk memperlihatkan distribusi variabel yang lebih jelas dan nyata dibandingkan dengan jika tidak dilakukan rotasi. Angka pembatas (cut of point) lebih dari 0,5 .

Tabel 6. Rotated Component Matrix ${ }^{\mathrm{a}}$

\begin{tabular}{lrrrrrr} 
& \multicolumn{7}{c}{ Component } \\
\cline { 2 - 7 } & \multicolumn{1}{c}{ 1 } & \multicolumn{7}{c}{3} & \multicolumn{1}{c}{4} & \multicolumn{1}{c}{5} \\
\cline { 2 - 7 } $\mathrm{X}_{1.1}$ & -.005 & .086 & .762 & -.100 & .072 & .031 \\
$\mathrm{X}_{1.2}$ & .069 & .092 & .843 & .051 & -.023 & -.034 \\
$\mathrm{X}_{1.3}$ & .066 & -.051 & .729 & .146 & .368 & .124 \\
$\mathrm{X}_{1.4}$ & .066 & .041 & .447 & .188 & .702 & .121 \\
$\mathrm{X}_{1.5}$ & .025 & .134 & .141 & .175 & .764 & -.046 \\
$\mathrm{X}_{2.1}$ & .590 & .124 & .262 & -.184 & -.258 & .023 \\
$\mathrm{X}_{2.2}$ & .815 & .119 & .124 & .108 & -.143 & .071 \\
$\mathrm{X}_{2.3}$ & .797 & .080 & .031 & .233 & .077 & .075 \\
$\mathrm{X}_{2.4}$ & .752 & .013 & -.086 & .101 & .296 & -.067 \\
$\mathrm{X}_{2.5}$ & .619 & .182 & -.120 & .051 & .387 & .151 \\
$\mathrm{X}_{3.1}$ & .087 & .411 & .078 & -.205 & .102 & .471 \\
$\mathrm{X}_{3.2}$ & .086 & .178 & .047 & .196 & .046 & .722 \\
$\mathrm{X}_{3.3}$ & -.012 & -.137 & .035 & .306 & -.011 & .808 \\
$\mathrm{X}_{3.4}$ & .057 & -.034 & -.055 & .750 & .127 & .211 \\
$\mathrm{X}_{3.5}$ & .139 & .180 & .047 & .814 & .117 & .105 \\
$\mathrm{X}_{3.6}$ & .122 & .325 & .088 & .698 & .117 & .071 \\
$\mathrm{X}_{4.1}$ & .046 & .803 & .098 & .194 & .007 & -.083 \\
$\mathrm{X}_{4.2}$ & .139 & .787 & .138 & .150 & -.012 & .075 \\
$\mathrm{X}_{4.3}$ & .150 & .722 & -.076 & .085 & .290 & .182 \\
$\mathrm{X}_{4.4}$ & .171 & .422 & -.079 & .016 & .463 & .381 \\
\hline
\end{tabular}

Extraction Method: Principal Component Analysis. Rotation Method: Varimax with

Kaiser Normalization.

a. Rotation converged in 8 iterations.

\section{Sumber : Data diolah, 2016}

Berdasarkan tabel di atas dapat dijelaskan satu per satu indikator mana yang akan masuk ke faktor atau variabel mana, sebagai berikut:

1. Tingkat keterjangkauan harga, faktor loading yang paling besar berada pada faktor 3 dengan korelasi sebesar 0.762 . Hal ini berarti Tingkat keterjangkauan harga berada pada faktor 3 .

2. Tingkat kesesuaian harga dengan kualitas produk, faktor loading yang paling besar berada pada faktor 3 dengan korelasi sebesar 0.843. Hal ini berarti Tingkat kesesuaian harga dengan kualitas produk berada pada faktor 3 .
3. Tingkat kesesuaian harga dengan rasa, faktor loading yang paling besar berada pada faktor 3 dengan korelasi sebesar 0.729 . Hal ini berarti Tingkat kesesuaian harga dengan rasa berada pada faktor 3, dan seterusnya.

Maka dari itu, dari 20 indikator yang direduksi dapat membentuk 6 faktor, yaitu:

a. Faktor 1 terdiri dari: Tingkat rasa sesuai dengan harapan, Tingkat varian rasa, Tingkat teksturnya, Tingkat variasi, Tingkat ketahanan produk. 
Rini \& Rusda,anal isis faktor-faktor yang dipertimbangkan konsumen dalam keputusan pembelian ....

b. Faktor 2 terdiri dari: Dikenal konsumen, Tingkat kemampuan bersaing, Tingkat pengalaman perusahaan.

c. Faktor 3 terdiri dari: Tingkat keterjangkauan harga, Tingkat kesesuaian harga dengan kualitas produk, Tingkat kesesuaian harga dengan rasa.

d. Faktor 4 terdiri dari: Bentuk mewah, Tingkat kemudahan dibuka, Tingkat kemudahan dibawa.

e. Faktor 5 terdiri dari: Tingkat kesesuaian harga dengan kemasan, Tingkat persaingan harga dengan produk pesaing yang sejenis, Tingkat reputasi yang baik.

f. Faktor 6 terdiri dari: Tingkat mutu, Tingkat daya tahan, Praktis.

\section{Interpretasi Atas Faktor Yang Terbentuk}

Setelah melakukan faktoring dan rotasi, langkah selanjutnya adalah menginterpretasikan faktor yang telah terbentuk. Hal ini dilakukan agar bisa mewakili variabel-variabel anggota faktor terbentuk. Menurut Hasan dalam Jayakusumah (2014), mengatakan pemberian nama dan konsep tiap faktor ditentukan berdasarkan makna umum variabel yang tercakup didalamnya.

Dari hasil penelitian dapat diketahui bahwa dari 20 indikator dapat terbentuk 6 faktor yang sebelumnya hanya terdiri 4 faktor. Berdasarkan teori Tjiptono (2008) dalam Sudrajad dan Andriani (2015) faktor-faktor yang dipertimbangkan konsumen dalam keputusan pembelian produk yaitu faktor harga, kualitas, kemasan dan merek.

Setelah dilakukan analisis faktor konfirmatori, diperoleh 6 faktor yang terbentuk. Berdasarkan penelitian Jayakusumah (2011) mengenai "Analisis Faktor-faktor Yang Mempengaruhi Konsumen Dalam Keputusan Pembelian Teh Celup Sariwangi didapat 8 faktor yang terbentuk diantaranya faktor Psikologis, Produk, Sosial, Distribusi, Harga, Promosi, Individu dan Pelayanan.

Sedangkan faktor yang paling dominan mempengaruhi konsumen dalam keputuan pembelian teh Sariwangi yaitu faktor psikologis dengan nilai varians $18.734 \%$. Berdasarkan hasil penelitian menggunakan analisis faktor konfirmatori dapat dijelaskan mengenai faktor baru yang terbentuk yaitu: Faktor Kualitas Produk, Brand Image, Harga Produk, Bentuk Kemasan, Competitor/Pesaing dan Mutu Kemasan yang merupakan faktor-faktor yang dipertimbangkan konsumen dalam keputusan pembelian produk Kek Pisang Villa.

Faktor Kualitas Produk yang menjadi pertimbangan konsumen sebelum membeli produk. Dalam kaitannya dengan objek penelitian yaitu Kek Pisang Villa, konsumen memiliki beberapa pertimbangan sebelum membeli produk Kek Pisang Villa diantaranya Tingkat rasa sesuai dengan harapan, Tingkat varian rasa, Tingkat teksturnya, Tingkat variasi, Tingkat ketahanan produk. Hal-hal tersebut yang perlu diperhatikan oleh perusahaan supaya meningkatkan daya beli konsumen terhadap produk Kek Pisang Villa. Semakin tinggi kualitas produk, maka semakin besar pula keinginan konsumen untuk membeli produk Kek Pisang Villa.

Faktor Brand Image ternyata juga dijadikan pertimbangan konsumen sebelum membeli produk. Dalam kaitannya dengan objek penelitian yaitu Kek Pisang Villa, konsumen memiliki beberapa pertimbangan sebelum membeli produk Kek Pisang Villa diantaranya Dikenal konsumen, Tingkat kemampuan bersaing, Tingkat pengalaman perusahaan. Hal ini sangat penting untuk ditingkatkan perusahaan mengenai citra merek perusahaan. Apabila citra merek suatu produk dikenal baik dan positif oleh konsumen, maka konsumen akan loyal terhadap produk yang dikonsumsinya.

Faktor Harga Produk merupakan hal yang paling sering dibicarakan konsumen. Dalam kaitannya dengan objek penelitian yaitu Kek Pisang Villa, konsumen memiliki beberapa pertimbangan sebelum membeli produk Kek Pisang Villa diantaranya Tingkat keterjangkauan harga, Tingkat kesesuaian harga dengan kualitas produk, Tingkat kesesuaian harga dengan rasa. Konsumen akan membeli suatu produk dengan harga yang terjangkau dan wajar. Maksudnya harga yang ditawarkan perusahaan sebaiknya jangan terlalu tinggi dan jangan pula terlalu rendah. Harga harus disesuaikan dengan kondisi pangsa pasar dan sesuai pula dengan produk yang dijual. 
Faktor Bentuk Kemasan termasuk hal penting yang jarang sekali diperhatikan perusahaan. Dalam kaitannya dengan objek penelitian yaitu Kek Pisang Villa, konsumen memiliki beberapa pertimbangan sebelum membeli produk Kek Pisang Villa diantaranya Bentuk kemasan mewah, Tingkat kemudahan dibuka, Tingkat kemudahan dibawa. Selain kualitas, citra merek dan harga produk biasanya kemasan juga dipertimbangkan konsumen sebelum membeli produk. Apalagi konsumen yang datang dari luar kota/negeri, mereka pasti memilih kemasan yang mewah, mudah dibuka dan dibawa sebagai nilai tambah. Karena lebih terkesan sosialita dan terlihat lebih mahal sehingga adanya kesenangan tersendiri bagi konsumen. Hal tersebut perlu juga diperhatikan perusahaan supaya mengikuti perkembangan zaman yang semakin modern.

Faktor Competitor/Pesaing perlu diperhatiakan perusahaan karena hal ini juga menjadi pertimbangan masyarakat sebelum membeli produk. Dalam kaitannya dengan objek penelitian yaitu Kek Pisang Villa, konsumen memiliki beberapa pertimbangan sebelum membeli produk Kek Pisang Villa diantaranya Tingkat kesesuaian harga dengan kemasan, Tingkat persaingan harga dengan produk pesaing yang sejenis, Tingkat reputasi yang baik. Konsumen biasanya cenderung membandingkan harga produk yang sejenis serta kelebihan yang didapat setelah membeli produk. Sebelum penetapan harga sebaiknya perusahaan membandingkan dengan harga produk pesaing seperti Kek Buah Naga, Nay@dam yang memiliki level hampir sama. Selain itu penting pula memperhatikan kelebihan apa saja yang diberikan perusahaan atas produk Kek Pisang Villa yang menjadi keunggulan produk.

Faktor Mutu Kemasan menjadi hal yang lazim dipertimbangkan konsumen dalam pembelian produk. Dalam kaitannya dengan objek penelitian yaitu Kek Pisang Villa, konsumen memiliki beberapa pertimbangan sebelum membeli produk Kek Pisang Villa diantaranya Tingkat mutu kemasan, Tingkat daya tahan, Praktis. Apabila kualitas, citra merek, harga produk, daya tarik praktis kemasan dan pesaing sudah memenuhi keinginan konsumen melainkan mutu kemasan tidak sesuai maka konsumen juga tidak akan melakukan pembelian untuk kedua kalinya. Hal tersebut juga menjadi pertimbangan konsumen khususnya untuk konsumen dari luar kota/negeri, karena sangat berpengaruh pada saat konsumen membawanya. Mutu kemasan yang baik maka akan mencerminkan produk yang berkualitas pula.

Sedangkan pada tabel Total Variance Explained dapat dilihat bahwa faktor yang paling dominan dipertimbangkan konsumen dalam keputusan pembelian produk Kek Pisang Villa adalah faktor kualitas produk dengan nilai varians sebesar $24.322 \%$, terdiri atas Tingkat rasa sesuai dengan harapan, Tingkat varian rasa, Tingkat teksturnya, Tingkat variasi, Tingkat ketahanan produk. Maka dari itu perusahaan sangat penting memperhatikan hal tersebut untuk meningkatkan omset perusahaan.

\section{KESIMPULAN DAN SARAN Kesimpulan}

Berdasarkan analisis dan pembahasan dari hasil penelitian faktor-faktor yang dipertimbangkan konsumen dalam keputusan pembelian produk Kek Pisang Villa kota Batam, maka dapat ditarik kesimpulan melalui analisis faktor konfirmatori sebagai berikut:

1. Faktor-faktor yang dipertimbangkan konsumen dalam keputusan pembelian produk Kek Pisang Villa kota Batam terdapat 6 faktor, yaitu:

a. Faktor Kualitas Produk, indikator pembentuknya adalah Tingkat rasa sesuai dengan harapan, Tingkat varian rasa, Tingkat teksturnya, Tingkat variasi dan Tingkat ketahanan produk.

b. Faktor Brand Image, indikator pembentuknya adalah Dikenal konsumen, Tingkat kemampuan bersaing dan Tingkat pengalaman perusahaan.

c. Faktor Harga Produk, indikator pembentuknya adalah Tingkat keterjangkauan harga, Tingkat kesesuaian harga dengan kualitas produk dan Tingkat kesesuaian harga dengan rasa.

d. Faktor Bentuk Kemasan, indikator pembentuknya adalah Bentuk kemasan mewah, Tingkat kemudahan dibuka dan Tingkat kemudahan dibawa.

e. Faktor Competitor/Pesaing, indikator pembentuknya adalah Tingkat kesesuaian harga dengan kemasan, Tingkat persaingan harga dengan 
Rini \& Rusda,anal isis faktor-faktor yang dipertimbangkan konsumen dalam keputusan pembelian ....

produk pesaing yang sejenis dan Tingkat reputasi yang baik.

f. Faktor Mutu Kemasan, indikator pembentuknya adalah Tingkat mutu kemasan, Tingkat daya tahan dan Praktis.

Dari faktor-faktor yang terbentuk, faktor yang paling dominan dipertimbangkan konsumen dalam keputusan pembelian produk Kek Pisang Villa adalah faktor kualitas produk dengan nilai varians sebesar $24.322 \%$, terdiri atas Tingkat rasa sesuai dengan harapan, Tingkat varian rasa, Tingkat teksturnya, Tingkat variasi, Tingkat ketahanan produk. Maka dari itu perusahaan sangat penting memperhatikan hal kualitas produk untuk meningkatkan omset perusahaan.

\section{Saran}

Berdasarkan kesimpulan di atas, maka saran-saran untuk dijadikan bahan masukan kepada perusahaan PT. Indonesia Villajaya untuk meningkatkan penjualan Kek Pisang Villa kota Batam yaitu:

Sebaiknya perusahaan lebih memperhatikan faktor apa saja yang dipertimbangkan konsumen dalam pembelian produk Kek Pisang Villa. Faktor-faktor yang harus diperhatikan yaitu faktor Kualitas Produk, Brand Image, Harga Produk, Bentuk Kemasan, Competitor/Pesaing dan Mutu Kemasan. Perusahaan perlu meningkatan rasa kek, menambah varian rasa, memperhatikan kelembutan teksturnya serta ketahanan kek. Perusahaan juga perlu meningkatkan promosi baik melalui media cetak maupun media sosial sehingga merek Kek Pisang Villa lebih dikenal masyarakat. Selain itu dalam penetapan harga perlu mempertimbangkan beberapa hal seperti keterjangkauan harga dengan ekonomi masyarakat, perlu disesuaikan juga dengan produk yang dijual sehingga harga yang ditawarkan terlihat wajar dan konsumen juga tidak kecewa membeli dengan harga yang ditawarkan. Tidak hanya produk dan harga, kemasan juga sangat penting diperhatikan perusahaan. Kemasan yang berkualitas tinggi juga menambah nilai jual suatu produk itu sendiri.

Sedangkan faktor yang dominan harus diperhatikan perusahaan adalah faktor kualitas produk artinya perusahaan harus memperhatikan proses produksi Kek Pisang Villa mulai dari persiapan bahan baku sampai dengan pendistribusian produk. Kek pisang merupakan jenis produk yang tidak tahan lama sehingga perlu diperhatikan penyimpanannya dan masa kadaluarsanya. Selain itu produk Kek Pisang Villa perlu menambah varian-varian baru sehingga produk tersebut berkembang dan konsumen tidak merasa bosan membeli produk Kek Pisang Villa.

\section{Keterbatasan}

Berdasarkan penelitian yang dilakukan penulis, adapun keterbatasan penelitian ini sebagai berikut:

1. Penelitian ini hanya fokus pada 4 variabel saja sehingga untuk kedepannya dapat menambah variabel dan jumlah sampel yang lebih banyak dari penulis untuk menambah pengetahuan mengenai faktor-faktor yang dipertimbangkan konsumen dalam keputusan pembelian produk.

2. Penulis menggunakan metode varimax saat melakukan rotasi pada analisis faktor konfirmatori, sebaiknya peneliti selanjutnya yang menggunakan analisis faktor konfirmatori dapat mencoba metode rotasi quartimax, equamax dan parsimax.

\section{DAFTAR PUSTAKA}

Abdullah, Prof.Dr., \& Tantri, Dr. (2012). Manajemen Pemasaran. Jakarta: PT Rajagrafindo Persada.

Aneja, N.Dr. (2014). Specific Factors and Their Degree of Influence in Cosmetic Product. Sai Om Journal of Commerce \& Management, 1 (3), 1-6.

Ichwan, C. (2011). Pengaruh Atribut Produk Terhadap Keputusan Pembelian, 1-19.

Indarti. (2010). Analisis Faktor-Faktor Yang Dipertimbangkan Konsumen Kosmetika Dalam Keputusan Pembelian Produk 
Pemutih Wajah. Jurnal Wacana, 13 (4), 606-614.

Jariah, A. (2012). Analisis Faktor-Faktor Pribadi Yang Mempengaruhi Keputusan Pembelian Sepeda Motor Yamaha di Lumajang. Jurnal WIGA, 2 (2), 1-18.

Jayakusumah, H. (2011). Analisis Faktor-Faktor Yang Mempengaruhi Konsumen Dalam Keputusan Pembelian Teh Celup Sariwangi. Skripsi, 1-141.

Liwe, F. (2013). Kesadaran Merek, Keragaman Produk dan Kualitas Produk Pengaruhnya Terhadap Pengambilan Keputusan Konsumen Membeli di Kentucky Fried Chicken Manado. Jurnal EMBA, 1 (4), 2107-2116.

Marisca, M. (2014). Analisis Faktor Konfirmatori Untuk Tingkat Kepuasan Pengunjung Perpustakaan Universitas Negeri Jakarta. Skripsi, 1-131.

Nilowardono, S. (2007). Identifikasi dan Analisis Faktor-Faktor Yang Mempengaruhi Konsumen Dalam Membeli Handphone Nokia (Studi Kasus Konsumen Surabaya). Jurnal Ekonomi, 7 (2), 14-27.

Persulessy, G. (2008). Analisis Faktor-Faktor Yang Mempengaruhi Keputusan Konsumen Dalam Memilih Operator Seluler (Studi pada Sebuah Perguruan Tinggi di Yogyakarta). Jurnal Fokus Ekonomi, 7 (3), 155-163.

Sari, R.D.K. (2012). Analisis Pengaruh Kualitas Produk, Persepsi Harga dan Word of Mouth Communication Terhadap Keputusan
Pembelian Mebel Pada CV Mega Jaya Mebel Semarang. Skripsi, 2 (2), 1-64.

Sata, M. (2013). Factors Affecting Consumer Buying Behavior of Mobile Phone Device. Mediterranean Journal of Social Science, 4 (12), 2039-2117.

Sudrajad, A.B., Andriani, D.R. (2015). Pengaruh Atribut Produk Terhadap Keputusan Konsumen Dalam Pembelian Produk Abon Jamur Tiram di Perusahaan Ailanifood Kota Malang Jawa Timur. Jurnal Habitat, 26 (2), 71-79.

Sugiyono. (2008). Metode Penelitian Bisnis. Bandung: Alfabeta.

Supartono., Khuzaini. (2007). Analisis FaktorFaktor Bauran Pemasaran Yang Dipertimbangkan Konsumen Dalam Keputusan Pembelian Ice Cream "Mini Melts" di Kota Surabaya. Jurnal Akuntansi, Manajemen Bisnis dan Sektor Publik, 3 (3), 373-395.

Supranto, Prof.Dr.J., Limakrisna, N. (2011). Perilaku Konsumen dan Strategi Pemasaran. Jakarta: Mitra Wacana Media.

Uddin, R.Md., Lopa, N.Z., Oheduzzaman, Md. (2014). Factors Affecting Customer's Buying Decisions of Mobile Phone: A Study on Khulna City Bangladesh. International Journal of Managing Value and Supply Chains, 5 (2), 21-28.

Wiguna, S.P. (2007). Pengaruh Kemasan Produk Terhadap Keputusan Konsumen Dalam Membeli Produk Jajan Khas Kota Gresik. $\quad$ Skripsi, $\quad 1-80$. 